two tons capacity. Provision is made for three explorers, a pack of dogs, two sleds, a boat, \&c., and, when completely equipped, the ship weighs about five tons.

Owing to the few opportunities of inspecting aëroplanes in this country in the past, these machines at Olympia are easily first in public interest. Included among them is the aëroplane, of French make, used by Mr. J. T. C. MooreBrabazon, who was one of the first two Englishmen actually to fly. The machine is a bi-plane, i.e. two planes one above the other, built by Voisin, there being 2 metres' distance between the planes, and it is fitted with an eight-cylinder E.N.V. engine. Three flights of from one to two kilometres, and about a dozen flights of from one to five kilometres, at a height up to 50 feet, have been made with this machine.

The Société Commercial des Automobiles Gobron-Brillie show an unfinished Breguet aëroplane of the bi-plane type. This machine is fitted with means of warping the planes differentially, which is intended to produce automatic balancing, to facilitate turning, and to act as an elevating
rudder.

A British-made aëroplane, designed by $\mathrm{Mr}$. Weiss, is shown by Handley Page, of Woolwich. The machine is a monoplane, having a span of 34 feet and an area of 150 square feet. There are two propellers driven by a 12 horsepower three-cylinder motor, air-cooled. Steering is effected by means of two flaps placed at the back of the main plane.

The Miesse Petrol Car Syndicate show a machine having wings, which are given a bird-like movement by an ingenious mechanism. Messrs. Short Brothers, of Battersea, show a bi-plane, and also an inflated balloon of 11,000 cubic feet capacity constructed for the Hon. C. S. Rolls. A bi-plane designed by W. Windham, of St. John's Hill, is shown, but, like several of the other machines, has not yet been tried. The Continental Tyre and Rubber Co., of Clerkenwell Road, show an inflated passenger balloon of 49,000 cubic feet capacity.

Mr. Howard T. Wright, of Marylebone, shows a beautifully constructed bi-plane, the main planes being 40 feet wide and 6 feet 6 inches deep. There are two propellers running in opposite directions driven by a 20 horse-power motor. Vertical steering is provided for by a double rudder in front of the main planes, and horizontal steering by a vertical rudder in the tail. Messrs. Lamplough and Son, Ltd., of Willesden Junction, show a compound lifter plane and glider. The design is the first of its kind, and awaits trial.

Mr. Frederick R. Simms shows a Simms-Voisin bi-plane of the type used by Farman, Delagrange, and Fournier in their flights. The main planes are 32.8 feet long, 6.5 feet wide, 5 feet space; the rudder cell or tail is 8.5 feet wide, 5 feet space, and contains a vertical rudder for horizontal steering. Vertical steering is secured by a horizontal rudder in front of the main planes. The total length is 37.8 feet; the weight complete is $1500 \mathrm{lb}$. The 50 horsepower motor has six cylinders, and weighs $528 \mathrm{lb}$. complete with water and petrol for a two hours' run. The propeller is 7 feet 5 inches diameter, 5 feet pitch, and weighs $33 \mathrm{lb}$.

An R.E.P. monoplane is shown by the Etablissement Robert-Esnault-Pelterie. This machine won third prize for 200-metre flight last year, the wind having a speed of 6 metres to 8 metres. A Delagrange bi-plane, by Voisin, is shown by the Mass Cars firm. The Cody war kite is on view by permission of the War Office. Messrs. Willows show a dirigible balloon built at Cardiff. Conspicuous among the exhibits of motors are those of the Wolseley Tool and Motor Car Co., Ltd., and also those of Messrs. John I. Thornycroft and Co., Ltd. It is unfortunate that no machine used by the Wright brothers is on view, although a small model of one may be scen.

The exhibition is well worth a visit, and shows that manufacturers in this country are alive to the potentialities of recent developments in France and other countries, and are taking steps not to be left behind in the race for the conquest of the air. It will assist in arriving at a proper estimation of the value of the exhibition if the fact is realised that all is as yet in the experimental stage, even in the case of the most successful of the machines shown.

\section{HIGHER EDUCATION IN THE UNITED} STATES.

THE report of the U.S. Commissioner for Education for the year ended on June 30 , 1907, has been received from Washington. This is the first report issued by Dr. Elmer E. Brown, who succeeded Dr. William T. Harris as commissioner on July 1,1906 . The two volumes, which together run to 1214 pages, deal exhaustively with every branch of American education, and in addition include valuable reviews of educational progress in many European and other countries.

The carefully arranged and remarkably complete tabulated statistics of the 606 universities, colleges, and technological schools of the United States, contained in the second volume, shows what valuable assistance our own Board of Education could render students and administrators of education if it would provide similar conspectuses concerning British institutions of higher learning.

From this part of the report we learn that the total value of all gifts and bequests reported by the 606 institutions referred to, as having been received during the year under review, amounted to $4,574,000 l$. Of this amount about $\mathrm{I}, 540,000 \mathrm{l}$. was given for buildings and improvements, and 2,540,00ol. for endowment. The remaining amount was for current expenses. Forty-two institutions each received $20,000 l$. or more. The six institutions which benefited to the largest extent in this way were the University of Chicago, which received some $1,189,000 \mathrm{l}$; the Rensselaer Polytechnic Institute, of New York, with its 215,400l.; Yale University, 198,00ol.; Cornell University, 156,0ool.; Princeton University, New Jersey, 153,00ol.; and Harvard University, $\mathbf{1 3 9 , 0 0 0 l .}$

The report shows that the Washington Bureau of Education received full particulars for the year which ended in June, 1907, from 606 universities, colleges, and technological institutions in the United States. Of these institutions, 150 are for men only, and 330 are open to both men and women. The teaching force of the whole of the institutions aggregated 24,679 - an increase of 729 teachers of different grades over the preceding year. The total enrolment of students was 293,343. Leaving out colleges for women only, and dealing with the remaining 480 institutions, tables are provided in the report which show that, in the session 1906-7, 3,399,00ol. was received by students' fees, $782,000 l$. being for board and other noneducational purposes.

The amount received from productive funds was $\mathrm{x}, 955,000 l$. $;$ the receipts from State or city for increase of plant were $755,000 l$., for endowment $45,000 l$, and for current expenses $1,628,000 l$. From the United States Government certain of the institutions, including agricultural and mechanical colleges, received 533,0ool. The grand total of the receipts of these 480 colleges from every source was $13,616,000 l$. Exclusive of amounts for endowment purposes, the total sum available for current expenses, improvements, and building was $11,08_{3}, 000 l$. These institutions had in the year under review in their libraries $12,472,530$ volumes, valued at about $3,6 r_{3}, 000 l$. The value of their scientific apparatus, machinery, and furniture was $5,639,000 l$., and of grounds and buildings 48,8 r6, oool., while their productive funds reached $50,238,000 l$.

Some aspects of higher education in the United States are dealt with in an article by Prof. R. C. Maclaurin, president-elect of the Massachusetts Institute of Technology, which appeared in the Revue scientifique of January I6 under the title "L'Enseignement technique superieur aux États-Unis." After referring to the interest taken in France in the progress of technological education, Prof. Maclaurin remarks that the European suspects an excessive development of the utilitarian spirit across the Atlantic, and thinks that America's enthusiasm for her own institutions too often displays some lack of the critical faculty ; but it is maintained that a good deal of the right spirit is at work, and that the problems of education in America are being attacked with seriousness and strength of purpose. Referring to the better technological institutions in the United States, the article points out that judged by French standards, the expense of conducting 
them is very great. It is not generally known that all the better institutions are developing so rapidly that their large revenues are inadequate.

It is often thought that in America there is an excessive expenditure on buildings and grounds, but this expenditure has been greatly exaggerated, and as to equipment, many American institutions are far behind the best of those in Europe. The number of professors is large, and in many cases this fact arises from excessive teaching or too much specialisation. In the best schools, however, it is due to an effort to encourage close relations between teacher and student. The administrative side of American institutions is highly developed, and, in fact, in matters of organisation and administration American institutions differ markedly from those in other countries. In the best schools a strong effort is made to avoid an excess either of "theory" or of "practice." The length of the course is usually four years, with a tendency to establish fifth-year courses for post-graduate study. Great importance is attached to means for keeping the schools in close touch with industry. One means of effecting this is the custom of encouraging professors to take an active part in the practice of their profession.

The Massachusetts Institute of Technology is described in detail. The property of the institute is valued at about $800,000 l$; its annual expenditure is about roo,oool. There are about 1500 students, and the annual fee is $50 l$. The teaching staff consists of about two hundred men, of whom nearly half are professors. The programme of studies involves thirteen different courses, each leading to the degree of Bachelor of Science. The student is free to choose whatever course he names, but in any given course most of the work is prescribed, although there is always a considerable number of options. The studies are not purely "professional"; a certain amount of modern languages, literature, history, and even of political economy is provided for. Prof. Maclaurin directs attention to special features of the institution, such as the facility offered for researches in chemistry, physics, and sanitary science. For this research work special laboratories are provided. The chemical laboratories are planned to hold about a thousand students. The chemical department occupies forty-five rooms, including twenty-five laboratories, four lecturerooms, a library, three rooms for weights and measures, and so on. The laboratory of chemical research occupies six separate rooms, and the chemical library has 10,000 volumes.

Prof. Maclaurin doubts the wisdom of separating science and technology. He thinks that a properly managed institute of technology should be an admirable training ground even for the man destined to devote his life to the advancement of "pure" science. It would avoid that separation of head and hand that is so bad for both. Science is sometimes in danger of becoming preoccupied with abstractions; its detachment from practice deprives it of a much needed stimulus, and makes for the detriment both of science and technology.

\section{SOME BIRD-PAPERS.}

ORSERVATIONS made in the neighbourhood of Tunbridge Wells have led Messrs. C. J. and H. G. Alexander to conclude that in the case of many of our migratory species of birds, each pair occupies a definite and restricted area during the breeding-season, into which other pairs of the same species do not intrude. This has led to the formulation of a scheme for mapping the individual distribution of such migratory birds in their breeding-haunts, the details of this plan being explained by the authors in the March number of British Birds. In noting on the map the nesting-area of any particular pair of birds, the authors generally relied upon the singing of the cock in one special spot. A reproduction of the Ordnance Survey map on the 6 -inch scale of a small district in the neighbourhood of Tunbridge Wells, on which have been marked the nesting-areas of the individual pairs of migratory birds, serves to illustrate the plan.

To vol. vi., part v., of Annotationes Zoologicae No. 2056, VOL. 8o]
Japonenses, Mr. M. Ogawa contributes a hand-list of the birds of Japan, arranged on the same plan as the British Museum "Hand-list of Birds."

In a paper on the kingfishers commonly known under the generic designation of Pelargopsis, published as No. 1657 of the Proceedings of the U.S. National Museum (vol. xxxv., p. 657), Mr. H. C. Oberholser proposes to abolish that name, on account of insufficient definition, and to replace it by Ramphalcyon of Reichenbach. If the innovation be adopted, it may be hoped that the spelling of the name will be amended, and also that ornithologists will not follow the author in using the absurd designation Ramphalcyon capensis capensis for the typical race of a species restricted to the Malay Islands. Ornithologists have generally considered the sexes of these kingfishers to be externally indistinguishable, but this $\mathrm{Mr}$. Oberholser points out is incorrect, the females being generally larger than the males, with the back and wings, and sometimes also the tail, duller and browner or greener in colour.

The January number, vol. viii., part iii., of the Emu contains the second part of a paper, by Mr. A. H. E. Mattingley, on the mallec-fowl (Lipoa ocellata), which is largely devoted to the eggs, young, and nesting-mounds of these remarkable birds. The Lipoa does not commence to lay until two years old, and during the first half of the breeding-season the eggs are laid regularly every third or fourth day, after which the intervals between the deposition of the eggs increase according to the disposition of the individual birds and the amount of food available. Hot and dry seasons have a noticeable effect on these birds, which under such conditions lay fewer eggs than usual. Laying usually commences early in September, but may be deferred until December is well advanced, and the total number of eggs laid by the individual hens in a season varies from one to a score. The eggs have unpolished shells of a delicate salmon-pink or pinkish-red colour when first laid, but soon fade to earthy-brown. They are laid in the mound in tiers, with four in the basement tier; between each tier is a layer of sand 3 or 4 inches thick, and the eggs in the same time are separated from one another by from 6 to 12 inches of the same material, and placed near the solid wall of decaying vegetable matter bounding the egg-chamber. The eggs are always placed with the narrow end downwards, so that when hatching the head of the chick, which occupies the larger end, will be uppernost.

In the Times of March $3 \mathrm{Mr}$. P. McKenzie announces the shooting in the Polela district of Natal of a white stork, which bore on one leg a metal band with the inscription "Ornith. Köspont, Budapest, Hungaria, 209." To this letter there appeared in the same journal for March 17 a reply from Dr. O. Hermann, director of the Roval Hungarian Central Burcau for Ornithology, stating that the bird in question was liberated in Transylvania in July, 1908. This, taken with another event of the same nature, serves to settle the disputed question whether European storks cross the equator on their winter migration.

To the February number of the Victorian Naturalist Mr. A. J. Nuth contributes notes on the habits of Australian bower-birds. After alluding to the fact that the species of the genera Ptilonorhynchus and Chlamydodera adorn their bowers chiefly with bones, next to which come shells, stones, berries, and fragments of metal, while Prionodura uses flowers alone, and thus approaches the Papuan gardener-bird (Amblyornis), the author points out that the tooth-billed Scenopoeetes dentirostris forms a connecting link, in the matter of habits, between the more typical bower-birds and the cat-birds (Æluredus). In place of constructing a bower, the tooth-billed species merely clears a space, which it decorates with leaves, usually placed with the under surface uppermost; cat-birds, on the other hand, neither build a bower nor clear a space. Special attention is directed to the bowers of Newton's bower-bird (Prionodura newtoniana), some of which are stated to be more than 8 feet in height, and are decorated with flowers, generally orchids. At the larger bowers males alone are usually seen during the nestings-season, as the females are engaged elsewhere. 